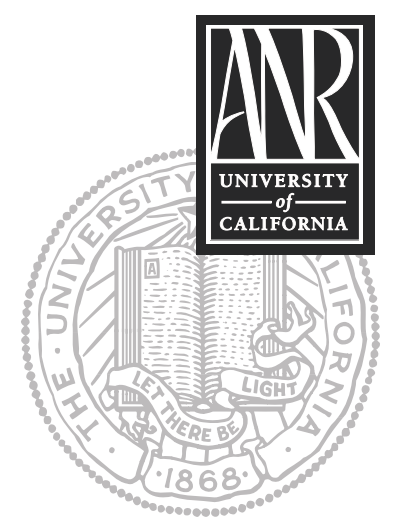

UNIVERSITY OF CALIFORNIA

Division of Agriculture and Natural Resources http://anrcatalog.ucdavis.edu

\title{
NUTRITION AND HEALTH INFO SHEET Soy
}

KARRIE HENEMAN, Assistant Project Scientist, Department of Nutrition, University of California, Davis; FRANCENE STEINBERG, Associate Professor, Department of Nutrition, University of California, Davis; SHERI ZIDENBERG-CHERR, UC Cooperative Extension Nutrition Science Specialist, Department of Nutrition, University of California, Davis

\section{What is soy?}

Soy is a low-cost source of protein that has been consumed in Asian nations for many centuries. This food contains fiber, minerals, and isoflavones (a type of flavonoid), all beneficial nutrients that may contribute to a reduction in chronic disease risk. Regular intake of this food is thought to be partially responsible for the lower rates of heart disease, stroke, and cancer observed in Asian populations. Due to concerns that have been raised by the use of hormone replacement therapy, many researchers are looking to soy as a possible natural alternative to prevent some of the symptoms associated with menopause. ${ }^{1}$ (The superscript numbers refer to entries in the reference list.)

\section{What are the isoflavones contained in soy?}

The isoflavones genistein, daidzein, and glycitein are the flavonoid components of soy protein. Also known as phytoestrogens, these compounds are structurally similar to the hormone estrogen, and they interact with estrogen receptors in the body. Many researchers believe that the isoflavones may be an "active" component of soy, along with soy-specific proteins, that are responsible for the beneficial effects observed after soy consumption. ${ }^{1}$

\section{What are good sources of soy?}

There are many soy products out on the market; however, most of these have undergone such high levels of processing that much of the nutritional benefit is lost. Below is a listing of high-quality sources.

\section{Edamame or Soy Beans}

Soy beans are the least processed form of soy protein. Available in most grocery stores, they can be purchased in fresh, frozen, or roasted forms. These beans can be eaten alone, like peas, or added to salads and stir-fries.

\section{Tofu}

Tofu, or bean curd, is made by curdling soymilk with a coagulant. Available in both soft and firm forms, tofu can be used in a variety of recipes to partially replace either meat or dairy products. Due to the common use of calcium sulfate as the curdling agent, tofu can also be a good source of calcium. A $1 / 2$ cup serving may contain as much as $130 \mathrm{mg}$ of calcium. (See the metric conversion table at the end of this publication.)

\section{Soymilk}

Soymilk is another high-quality source of soy protein that is available in a variety of forms, including plain, vanilla, and chocolate. It can be used to replace milk added to coffee, tea, or cereal. A one-cup serving can have as much as $300 \mathrm{mg}$ of calcium. 


\section{Why should people eat soy?}

Epidemiological studies suggest that regular consumption of plant-based protein foods reduces one's risk for chronic diseases such as cancer, heart disease, and stroke. . $^{3,4,5,6}$ Plant-based foods, such as soy, can provide the body with beneficial agents including vitamins, minerals, fiber, and flavonoids. Numerous clinical trials have investigated the potential of soy to protect against the risk of chronic disease. Below is a listing of some of these findings.

\section{Soy and Heart Disease}

Consumption of soy protein has been associated with decreasing the susceptibility of LDL cholesterol to oxidation, reducing arterial stiffness, lowering total and LDL cholesterol, and increasing HDL cholesterol, possibly reducing the risk of coronary artery disease. $^{2}$

\section{Soy and Cancer}

Numerous studies have investigated the anticarcinogenic properties of soy. Regular consumption of soy protein by healthy adult populations has been associated with a reduction in risk of both breast and prostate cancer. It has been suggested that the isoflavones genistein and daidzein may decrease the amount and size of cancer tumors. ${ }^{2}$ As with any significant dietary change, women with breast cancer or elevated risk for this disease should consult their physician before adding soy to their diet.

\section{Soy and Osteoporosis}

Due to the similarity in the structures of the isoflavones and estrogen, several studies are investigating the ability of isoflavones to reduce the rapid rate of bone loss that is associated with the onset of menopause. Epidemiological evidence has shown that Asian women, who consume the highest levels of soy protein, have elevated bone mineral density and lower risk of fracture. ${ }^{1,6}$

\section{Soy and Diabetes}

Regular consumption of soy protein may help to reduce symptoms associated with Type 2 Diabetes. Soy has been shown to decrease postprandial hyperglycemia, improve glucose tolerance, and decrease amounts of glycosylated hemoglobin. ${ }^{7}$

\section{Soy and Obesity}

A recent observational investigation in postmenopausal women found a favorable association between regular consumption of soy protein and a lower body mass index, higher HDL cholesterol concentration, and lower fasting insulin levels. ${ }^{7}$ More research must be completed before any firm conclusions can be made.

\section{How much soy is recommended?}

According to the American Heart Association and the US Food and Drug Administration (FDA), soy products have beneficial nutrient profiles and daily consumption of 25 grams or more of soy protein with isoflavones can help lower cholesterol levels in individuals at high risk for heart disease. ${ }^{8}$ An average serving of soy foods provides 6.25 grams of soy protein, so an individual who is trying to lower his or her cholesterol should aim for eating four servings of high-quality soy foods a day. If a breast cancer patient, or person who is at high risk for this disease, enjoys eating soy, occasional consumption does not appear to pose any risk; however, these individuals should consult their physicians before adding soy to their diets. ${ }^{9}$ 


\title{
Can too much soy be harmful?
}

Numerous clinical studies have found that daily consumption of up to 50 grams of soy protein is not only safe, but may also be effective in improving risk factors for chronic disease such as some types of cancer, diabetes, and cardiovascular disease. ${ }^{8}$ For individuals with, or at high risk for, breast cancer, there appears to be no adverse effects of occasionally eating soy, ${ }^{9}$ especially if it is enjoyed as part of a low-fat, high-fiber diet.

\section{What are some ways to increase soy intake?}

Below is a list of suggestions to help you achieve the American Heart Association and the FDA's recommended four servings of soy per day.

\author{
Replace some or all of the meat in your favorite recipes with tofu or texturized vegetable \\ protein (TVP). \\ - In spaghetti sauce, replace half of your ground beef with TVP. \\ - In stir-fry or fajitas, replace the usual chicken or beef with cubed firm tofu. \\ - In chili, replace half of your ground beef with TVP. \\ - Make tacos with TVP. \\ - Add some TVP to meatloaf.
}

Use silken tofu to replace sour cream, yogurt, or cheese in recipes.

- Make a dip for vegetables with half silken tofu and half sour cream. Add one package of dried onion soup mix, combine in a blender, and serve.

- Make a morning smoothie with silken tofu instead of the usual yogurt.

- Replace half of the ricotta cheese with puréed firm tofu in lasagna.

- Use silken tofu to replace the heavy cream in your favorite soup recipe.

- Make a mixture of half sour cream and half silken tofu to use as a low-fat topping on baked potatoes.

Try some of the new soy products available at the super market.

- Replace your morning breakfast sausage with soy sausage.

- Try some of the numerous types of garden or soy burgers.

- Use soymilk instead of creamer in your morning coffee or tea or on your breakfast cereal.

- Use soy nuts as a salad topper or eat them alone as a snack.

- Try soy nut butter and jelly for your next brown bag lunch.

\section{Should people take isoflavone supplements?}

Although many researchers have attempted to isolate the active component of soy to create an effective soy supplement, there appears to be some additional benefit provided by consuming the intact protein, particularly for lowering cholesterol. Furthermore, the actual isoflavone content of any supplement cannot be guaranteed. For these reasons, it is recommended that people wishing to lower their cholesterol attempt to incorporate high-quality sources of soy protein into their diet rather than resorting to supplements. 


\section{Listed below are some common foods and their soy protein content.}

\begin{tabular}{|c|c|c|c|c|}
\hline Food & Serving & Soy Protein (g) & $\begin{array}{l}\text { Isoflavone Content* } \\
\text { (mg) }\end{array}$ & Calories \\
\hline soy burger & 1 patty & 8 & 7 & 100 \\
\hline soy nuts & $1 \mathrm{oz}$ & 12 & 38 & 150 \\
\hline soy milk & 1 cup & 8 & 24 & 100 \\
\hline texturized vegetable protein (TVP) & $1 / 4$ cup & 14 & 27 & 50 \\
\hline tofu & $30 z$ & 9 & 33 & 45 \\
\hline soy protein bar & 1 bar & 6 & $10-15^{+}$ & 180 \\
\hline soy breakfast pattie & 2 patties & 16 & 4 & 160 \\
\hline soy flour & $1 / 4$ cup & 12 & 33 & 90 \\
\hline soy beans, boiled & $1 / 2$ cup & 7 & 47 & 190 \\
\hline tempeh & $1 / 2$ cup & 18 & 36 & 200 \\
\hline soy nut butter & $2 \mathrm{Tbs}$ & 8 & 0 & 160 \\
\hline
\end{tabular}

Notes:

*Obtained from the USDA-lowa State University database on the isoflavone content of food.

${ }^{\dagger}$ Estimated from nutrition label information.

\section{REFERENCES}

1. Messina, M. J. 2002. Soy foods and soybean isoflavones and menopausal health. Nutr Clin Care 5: 272-282.

2. Kris-Etherton, P. M., K. D. Hecker, Bonanome, A., S. M. Coval, A. E. Binkoski, K. F. Hilbert, A. E. Griel, and T. D. Etherton. 2002. Bioactive compounds in foods: Their role in prevention of cardiovascular disease and cancer. Am J Med 113(9B): 71S-88S.

3. Cui, X., Q. Dai, M. Tseng, X. Shu, Y. Gao, and W. Zheng. 2007. Dietary patterns and breast cancer risk in the Shanghai Breast Cancer Study. Can Epi Bio Prev 16:1443-1448.

4. Kleijn, M. J. J. de, Y. T. van de Schouw, P. W. F. Wilson, D. E. Grobbee, and P. F. Jacques. 2001. Dietary intake of phytoestrogens is associated with a favorable metabolic cardiovascular risk profile in postmenopausal U.S. women: The Framingham study. J Nutr 132:276-282.

5. Nagata, C. 2000. Ecological study of the association between soy product intakes and mortality from cancer and heart disease in Japan. Int J Epidemiol 29:832-836.

6. Zhang, X., X. O. Shu, H. Li, G. Yang, Q. Li, Y. T. Gao, and W. Zheng. 2005. Prospective cohort study of soy food consumption and risk of bone fracture among postmenopausal women. Arch Int Med 165:1890-1895.

7. Bhathena S. J., and M. T. Velasquez. 2002. Beneficial role of dietary phytoestrogens in obesity and diabetes. Am J Clin Nutr 76:1191-1201.

8. Sacks, F. M, A. H. Lichtenstein, L. Van Horn, W. Harris, P. Kris-Etherton, and M. Winston. 2006. Soy protein, isoflavones and cardiovascular health. Circulation 113:1034-1044.

9. Messina, M. J., and C. L. Loprinzi. 2001. Soy for breast cancer survivors: A critical review of the literature. J Nutr 131:3095S-3108S. 


\section{METRIC CONVERSIONS}

\begin{tabular}{|l|c|c|l|}
\hline English & $\begin{array}{c}\text { Conversion factor for } \\
\text { English to metric }\end{array}$ & $\begin{array}{c}\text { Conversion factor for } \\
\text { metric to English }\end{array}$ & Metric \\
\hline grain & 64.80 & 0.015 & milligram (mg) \\
\hline fluid ounce (fl oz) & 29.57 & 0.034 & milliliter (ml) \\
\hline ounce (oz) & 28.35 & 0.035 & gram (g) \\
\hline
\end{tabular}

\section{FOR FURTHER INFORMATION}

To order or obtain printed ANR publications and other products, visit the ANR Communication Services online catalog at http://anrcatalog.ucdavis.edu. You can also place orders by mail, phone, or FAX, or request a printed catalog of our products from:

University of California

Agriculture and Natural Resources

Communication Services

6701 San Pablo Avenue, 2nd Floor

Oakland, California 94608-1239

Telephone: (800) 994-8849 or (510) 642-2431

FAX: (510) 643-5470

E-mail inquiries: danrcs@ucdavis.edu

An electronic version of this publication is available on the ANR Communication Services Web site at http://anrcatalog.ucdavis.edu.

This publication has been anonymously peer reviewed for technical accuracy by University of California scientists and other qualified professionals. This review process was managed by the ANR Associate Editor for Food and Nutrition.

Publication 8268

ISBN-13: 978-1-60107-504-8

(C) 2008 The Regents of the University of California

Division of Agriculture and Natural Resources

All rights reserved.

No part of this publication may be reproduced, stored in a retrieval system, or transmitted, in any form or by any means, electronic, mechanical, photocopying, recording, or otherwise, without the written permission of the publisher and the authors.

The University of California prohibits discrimination or harassment of any person on the basis of race, color, national origin, religion, sex, gender identity, pregnancy (including childbirth, and medical conditions related to pregnancy or childbirth), physical or mental disability, medical condition (cancer-related or genetic characteristics), ancestry, marital status, age, sexual orientation, citizenship, or status as a covered veteran (covered veterans are special disabled veterans, recently separated veterans, Vietnam era veterans, or any other veterans who served on active duty during a war or in a campaign or expedition for which a campaign badge has been authorized) in any of its programs or activities. University policy is intended to be consistent with the provisions of applicable State and Federal laws.

Inquiries regarding the University's nondiscrimination policies may be directed to the Affirmative Action/Staff Personnel Services Director, University of California, Agriculture and Natural Resources, 1111 Franklin Street, $6^{\text {th }}$ Floor, Oakland, CA 94607-5201, (510) 987-0096. For information about ordering this publication, telephone 1-800-994-8849.

pr-1/08-LR/CM 